\title{
Nietzsche, the Anthropologists, and the Genealogy of Trauma
}

\author{
Iain P. Morrisson
}

check for updates

Citation: Morrisson, Iain P. 2021. Nietzsche, the Anthropologists, and the Genealogy of Trauma. Genealogy 5: 23. https://doi.org/10.3390/ genealogy5010023

Received: 19 February 2021

Accepted: 10 March 2021

Published: 17 March 2021

Publisher's Note: MDPI stays neutral with regard to jurisdictional claims in published maps and institutional affiliations.

Copyright: (C) 2021 by the author. Licensee MDPI, Basel, Switzerland. This article is an open access article distributed under the terms and conditions of the Creative Commons Attribution (CC BY) license (https:// creativecommons.org/licenses/by/ $4.0 /)$.
The Honors College, University of Houston, Houston, TX 77204, USA; ipmorris@Central.UH.EDU

\begin{abstract}
In this paper, I bring the Second and Third Essays of On the Genealogy of Morality into conversation with the anthropological work that Nietzsche uses to inform his understanding of human prehistory. More specifically, I show the ways in which Nietzsche's genealogical use of prehistory both calls upon and departs from the work of figures like Edward Tylor, John Lubbock, and Albert Hermann Post. This departure is most significant in Nietzsche's rejection of the progressive or developmental account of social and moral history for an account that emphasizes the way in which morality develops out of the psychological effects of recurring human traumas.
\end{abstract}

Keywords: Nietzsche; genealogy; anthropology; prehistory; trauma

Though Nietzsche's genealogical approach to the nature and value of morality has often been heralded as a ground-breaking development in philosophy, it is worth remembering that the 19th century was one in which the study of history, broadly construed, flourished in a number of fields of inquiry. ${ }^{1}$ It was in this century that paleontology, geology, comparative philology, evolutionary biology, and prehistoric archaeology all developed rapidly and established themselves as academic disciplines. Indeed, historical development was a key idea in the Hegelian/Marxist philosophical schools as well as in the positivism of Auguste Comte. In this broader context, it is no surprise that modern scientific anthropology as an investigation into humankind's earliest social and cultural history exploded onto the scene in the 1860s and 1870s. It is against the backdrop of this new field of study that I want to consider Nietzsche's approach to genealogy in On the Genealogy of Morality.

Nietzsche started to explore the burgeoning field of anthropology about ten years before he wrote the Genealogy. In the late 1870s, he read translations of the major works of leading English anthropologists John Lubbock and Edward Tylor. ${ }^{2}$ As the field expanded so did Nietzsche's interest, such that by the early 1880s he was reading books by German scholars (influenced by Lubbock and Tylor) such as Albert Hermann Post and Otto Caspari. In the endnotes to their translation of the Genealogy, Clark and Swensen (1998) cite at least 12 references to Post (1881) in the Second Essay. However, as Thatcher (1983) has shown, the influence of contemporary anthropology went beyond discrete or isolated references; from late 1870s on, the lessons Nietzsche incorporated from the anthropologists shaped his understanding of human prehistory in crucial ways. Their work provided him with the confidence to make specific claims about the morally relevant psychological developments of prehistoric human types (e.g., contemplatives, warriors, and slaves). It is surely on the basis of just the kinds of detail that he picked up from the anthropologists' reconstruction of prehistory that Nietzsche claims, in the Genealogy, to be offering "a real history of morality ... [reflecting] that which can be documented, which can actually be confirmed and has actually existed" as opposed to the "English hypothesis-mongering into

1 For some heralding, see Deleuze (1983, p. 2) and Owen (2007, p. 144). For a more measured approach to the novelty of Nietzsche's method, see Kail (2011, pp. 215-18) and Schuringa (2014, pp. 253-56).

2 For more on Lubbock's influence on Nietzsche around the writing of the Human All Too Human series and Daybreak see Thatcher 1983. Thatcher's focus is on how Nietzsche's thinking about dreaming, animism, and customs was heavily indebted to Lubbock during this period. 
the blue" (Nietzsche 1997b, Pref. 7). ${ }^{3}$ These details gave Nietzsche the space from which to speak of his "grey" (Nietzsche 1997b, Pref. 7)—meaning meticulously documentedapproach in opposition to "English" figures like Hume and Rée. ${ }^{4}$

My focus in this essay is on how Nietzsche both digests and departs from the consensus of 19th century anthropology. While Nietzsche accepts many of the details on the genesis of human society from Lubbock, Tylor, and Post, he rejects the basic evolutionist or developmental framework in terms of which this genealogy is couched, and thus has to find alternative ways of identifying salient patterns in his histories of moral phenomena. In making this case, I steer clear of the most obviously historical and documented of Nietzsche's three essays, the First Essay, and focus instead on the Second and Third Essays. ${ }^{5}$ In particular, I argue in Section 3 that Nietzsche uses the anthropological evidence to help him spot recurring patterns of trauma-induced shifts in human psychology; these shifts are central to the development of the moral phenomena of guilt and asceticism in these essays. Before turning to Nietzsche's reception of the anthropology of his day in Section 2, I briefly explore, in Section 1, the conceptual contours of the developmental approach to society that characterizes this field.

\section{The Developmental Model of Social History}

Interest in what was called "primitive society" exploded in the 1860s and 1870s, starting in the English-speaking world. While advances in geology, archaeology, and paleontology had already given the earlier part of the century an historical flavor, the explanatory successes of evolutionary theories in biology in the 1860s and beyond opened more promising windows onto our human past. As these other scientific fields made great strides, the social sciences of anthropology, ethnology, comparative law, and sociology began to find their feet and to share an interest in reconstructing the development of prehistoric human societies. These reconstructions relied for support on the archaeological evidence of stone and metal artefacts, the accounts of ancient historians, and, perhaps most importantly, the veritable flood of new reports on indigenous peoples around the world. Lubbock's Origin of Civilization, for example, details the practices of hundreds of indigenous tribes from all over the world. On the premise that their cultures had somehow gotten stuck at a certain developmental level or even regressed, these tribes were seen as living clues as to what human prehistory must have looked like.

Therefore, just as geologists and paleontologists could reconstruct long lost historical periods and classify these periods into stages with laws governing the transitions from stage to stage, so these new social scientists imagined they could reconstruct, classify, and explain the development of human society. It is true, then, that while those scholars interested in the descent of human society were inspired by Darwin's successes on the question of biological descent, they were for the most part not Darwinians in the strict sense of believing that the conjunction of random mutations and environmental factors determined the evolutionary path of a given organism or entity. ${ }^{6}$ This is especially true of figures such as Tylor and Morgan, who shaped the field in arguing for a unilinear progression of human civilization from "lower" to "higher" stages. This view fit with a

3 Thus, contrary to the views of Craig (2007) and Kail (2011), who claim that there is no available evidence about human prehistory such that all claims about prehistoric developments must be purely and merely conjectural, the anthropologists that Nietzsche puts stock in believed that there was an abundance of evidence about human prehistory.

4 Though, in fairness to Rée (2003), he does briefly reference Lubbock and Tylor in The Origins of Moral Sensations.

5 Schuringa (2014), for example, does a good job of laying out some of Nietzsche's historical sources for the First Essay.

6 See Burrow (1966, p. 21) and Kuper (1988, p. 2). 
more teleological use of the term "evolution," according to which human society "evolved" toward an end already written into the implicit nature of the earliest humans.?

At the heart of this developmental model is the division of the stages of social progress into savagery (hunting and gathering), barbarism (nomadic pastoralism and eventually agriculture), and, finally, industrial civilization. This model roots human progress in technological advances, which both Tylor and Lubbock argue are matched by intellectual developments in understanding the world, and progress in moral principles and religious beliefs, as well as in social and political organization. The underlying view here is that all of these dimensions of human nature tend to unfold in conjunction with each other. ${ }^{8}$ It is no surprise, then, that for Tylor, "man's goodness, power, and happiness" (Tylor 1871, p. 24) all tend to improve as we move through the various correlated stages of technological, moral, religious, social, and political progress. ${ }^{9}$ Relatedly, fundamental similarities in human nature across place and time account for the fact that we are all moving in the same direction, albeit often at different speeds, and with some possibility of getting stuck. As Peter Bowler puts it: "The 'psychic unity' of humankind ensured that all races tend to progress in the same direction, along the same hierarchy of cultural stages" (Bowler 1988, p. 135). Post, for example, talks about "general forms of organization in ethnic life" being inherent in human nature, and claims that the unfolding of this nature explains the commonalities among the stages of development of customs and practices (Post 1880, pp. 12-15). ${ }^{10}$ It is an unfolding that follows what Post calls an "organic regularity (organische Gesetzmässigkeit)" (Post 1880, p. 35), with some tribes unfolding more quickly and efficiently than others.

Of course, the notion of universally shared progress in correlated human capacities producing gradual increases in goodness, power, and happiness is quite vague, to say the least. Without the kind of clearly defined criteria of progress one might find in describing the development of a science, for example, Tylor just says: "The educated world of Europe and America practically settles a standard by simply placing its own nations at one end of the social series and savage tribes at the other, arranging the rest of mankind between these limits according as they correspond more closely to savage or to cultured life" (Tylor 1871, p. 23). The end or telos of societal development, then, is provided by contemporary 19th century Western society with its high estimation of the monogamous

In fact, as Bowler (1988, p. 5) argues, even in biology itself the term evolution retained a basically teleological sense before the role of random mutations was fully incorporated into scientists' thinking. This extended even to Darwin himself; Moore writes: "the term 'evolution' originally referred to embryonic growth and was seldom used by Darwin himself to denote the transformation of species. In Germany, the term 'Entwicklung' was used to denote both ontogenetic [i.e., embryonic level] and phylogenetic i.e., [species level] development, because it was widely assumed that both processes were intimately related. 'Evolution' was understood literally, as an 'Ent-wicklung' or unfolding of preformed characteristics" (Moore 2002, p. 25 n.5). For biologists celebrating Darwin's achievements, the terms "evolution" "development" and even "perfection" were seen as interchangeable (Moore 2002, p. 29). Thus, even though Nietzsche read anthropologists like Lubbock and Caspari, who were quite familiar with Darwin's works, their positions did not represent a departure from the progressive model of the development of human society.

8 In J.S. Mill's System of Logic, published in 1840, he lays out this position: "States of society are like different constitutions or different ages in the physical frame; they are conditions not of one or of a few organs or functions but of the whole organism. Accordingly, the information which we possess respecting past ages, and respecting the various states of society now existing in different regions of the earth, does, when duly analysed, exhibit uniformities. It is found that when one of the features of society is in a particular state, a state of many other features, more or less precisely determinate, always or usually coexists with it" (Mill 2006, p. 912). Mill draws the following conclusion about this correlation of elements in a society: "The mutual correlation between the different elements of each state of society, is therefore a derivative law, resulting from the laws which regulate the succession between one state of society and another; for the proximate cause of every state of society is the state of society immediately preceding it" (Mill 2006).

9 Tylor relies heavily on technological advances as indicators of broader patterns in human development. In arguing for the idea of "species of implements or habits or beliefs being developed one out of another" he explains that "Mechanical invention supplies apt examples" (Tylor 1871, p. 13). It must be noted, however, that Lubbock (with whom Nietzsche was more familiar) writes: "I should rather be disposed to say that Man has, perhaps, made more progress in moral than in either material or intellectual advancement" (Lubbock 1875, p. 384).

10 All Post translations are mine. 
Christian family, the territorial state, and rationalized industrial production in a free market economy. $^{11}$

The evidence for movement toward such an end within a given society is provided in part by the notion of "survivals." From Tylor onwards, survivals are considered practices, customs, or beliefs that are carried by force of habit from one stage of society into later ones even when they no longer serve the same function in the later stage. The older practice or belief loses its earlier meaning or sense and yet is somehow kept up. Tylor writes: "The serious business of ancient society may be seen to sink into the sport of later generations" (Tylor 1871, p. 15).

More concretely, the anthropologists Nietzsche read tended to see progress toward the modern telos in terms of things such as increased articulation of conceptual distinctions in technology, religion, etc., increased specialization of social functions (i.e., division of labor), and increased differentiation of social classes and individuals. Along these lines, Lubbock and Post (amongst others) consider warfare a vital force in driving social development. Post, for example, argues that class divisions first enter society with the taking of slaves (Post 1880, p. 42). It follows that military success breeds a taste for hierarchy and differentiation of function. Of course, the capacities to follow clearly defined leadership and to differentiate military function further increases a community's chances of military victory and in turn promotes more progress in these areas. Lubbock loads much of this into the passing comment that the "whole history of man shows how the stronger and progressive, increase in numbers and drive out the weaker and lower races" (Lubbock 1875, p. 3). If social progress in organization and differentiation of function is not made, the tribe is "weaker and lower" and does not survive.

All things considered, however, the anthropologists' commitment to the idea of a unilinear progress through various stages of social formation outstrips the evidence for any such thing. Why then did they share such a commitment? This can be explained in terms of the conjunction of at least two factors: the remarkable surfeit of new details about indigenous peoples flooding the field and the intellectual climate of the time. Taking the latter first, the end of the 19th century was a time in which big sweeping narratives about culture and civilization were very much in vogue; both Lubbock and Tylor spend a significant amount of time in their major works refuting the still pervasive "degradation" theory of civilization. According to this more traditional and theologically inspired view, indigenous peoples represent a degradation in civilization; higher culture is seen as original and the emergence of "savage peoples" is a function of the degeneration of some groups (mostly through the ravages of war). Archbishop Whately, a leading advocate for this view, contends that "divine instructions and communications" (Whately 1832, p. 111) account for early man's civilized insights into the importance of private property and the division of labor.

In rejecting the popular degradation theory, the new anthropologists gave up the genealogical security assured to contemporary Europeans whose roots were traced to peoples very much like themselves in their cultural sensibilities (not to mention the religious security of having divinely inspired ancestors). With the abandonment of this position and a glut of new facts emerging about the seemingly infinite variety of human beliefs and practices, the anthropologists needed some other way of organizing the surfeit of facts,

11 Lubbock's understanding of the progress of religious ideas provides us with a specific illustration of this kind of teleologically developmental thinking. He introduces his thesis as follows: "I shall attempt to show that, though the religions of the lower races have received different names, they agree in their general characteristics, and are but phases of one sequence, having the same origin, and passing through similar, if not identical, stages" (Lubbock 1875, p. 196). In documenting the religious practices of hundreds of indigenous peoples, he identifies these stages not merely in terms of the nature of the object worshipped but primarily "the estimate in which the deity is held" (Lubbock 1875, p. 198). And thus Lubbock argues that religion progresses through the stages of Atheism, Fetichism, Totemism (or Nature-worship), Shamanism, Idolatry (or Anthropomorphism), Deity as creator of the natural world, and finally, Deity as moral agent. Lubbock's account makes clear that he is simply following Tylor's lead in placing the contemporary Christian conception of God, as omnipotent and omnibenevolent, at the end of progressive stages and ranking the other kinds of religion according to the extent to which they correspond to this Christian notion of God. So, for example, in the move from Fetichism to Totemism, "the higher deities are no longer regarded as liable to be controlled by witchcraft ... [though] they are not [yet] regarded as Creators" (Lubbock 1875, p. 326). Lubbock thus employs a couple of critical endpoints (omnipotence and omnibenevolence) in terms of which he can sort and rank the enormous quantity of data he presents. 
while at the same time assuring their cultural (and moral) superiority over "savages."12 For Tylor, this superiority is obvious in the contrast between average persons from both cultures, but is accounted for, and thus supported, by the theory of developmental progress. In this way, the mountains of evidence can be handled with the confidence of one who knows how the validating story ends and only tries to fill in the path to this end. ${ }^{13}$

\section{Nietzsche in the Context of the Anthropological Project}

From the beginning of the Human, All Too Human series on, it is clear that Nietzsche regards the anthropologists as allies in his battle against what he considers a metaphysical need in philosophers urging them to seek out "a miraculous source" (Nietzsche 1986b, sct. 1) for all things highly valued. He discovers a parallel to his battle against such ideas in the anthropologists' fight against Whately's degradation theory: "the origin of religion, art and morality ... can be perfectly understood without the postulation of metaphysical interference at the commencement or in the course of their progress" (Nietzsche 1986b, sct. 10). Just as the anthropologists' dogged interest in historical and prehistorical facts allows them resist the degradationist arguments about the requirement for supernatural interference, so Nietzsche resists the philosophers' supernatural importations: "Lack of historical sense is the family failing of all philosophers; many, without being aware of it, even take the most recent manifestations of man, such as has arisen under the impress of certain religions, even certain political events, as the fixed form from which one has to start" (Nietzsche 1986b, sct. 2). Far from being overwhelmed by the heaps of small facts in Lubbock and Post, for example, Nietzsche basks in the detailed reminders of cultural difference, complexity, and change; it is amongst these details that he finds the kinds of patterns that help explain the emergence of the complex phenomenon of contemporary morality.

However, Nietzsche rejects the comforting paradigm of cultural progress espoused by his anthropological sources. In particular, his view in the Genealogy that the morality of his culture expresses a kind of sickness that has taken root and held fast for two millennia is all the evidence we need of his dismissal of the idea of moral progress. ${ }^{14}$

At the same time, Nietzsche's refusal to accept the anthropologists' progressive model of historical development goes beyond morality and sits uneasily alongside his acceptance of their claims about the nature of prehistoric human life. In spite of Nietzsche's persistent adoption of the language of higher and lower cultures, and even "stages of culture" (Nietzsche 1986a, sct. 223), he rejects (from early on) the idea that these stages advance progressively toward some kind of cultural end. ${ }^{15}$ In the same passage, in which he deploys the newly discovered evolutionary facts in biology against the degradation theory, he closes the door on the highest aspirations of the progressive model as well:

Formerly one sought the feeling of the grandeur of man by pointing to his divine origin: this has now become a forbidden way, for at its portal stands the ape ... One therefore now tries the opposite direction: the way humankind is going shall serve as proof of his grandeur and kinship with God. Alas this, too, is vain! ... However, high humankind may have evolved—and perhaps at the end it will stand even lower than at the beginning! - it cannot pass over into a higher order, as little as the ant and the earwig can at the end of its 'earthly course'

12 Tylor refers to the "enormous complexity of evidence" (Tylor 1871, p. 3), which he finds "at once so multifarious and so doubtful" (Tylor 1871, p. 5)

13 Burrow (1966, p. 263) arrives at a similar conclusion arguing: "Theories of social evolution had provided for the Victorians an intellectual resting-place, a point of repose at which the tension between the need for certainty and the need to accommodate more diverse social facts ... than the traditional certainties allowed for reached a kind of temporary equilibrium."

14 One of Nietzsche's primary targets in the Genealogy, Rée (2003), has a chapter devoted to "Moral Progress."

15 In the same sentence in which Nietzsche talks about stages of culture, he refers to "so-called savage and semi-savage peoples (sogenannten wllden and halbwilden Völkerschaften)" (Nietzsche 1986a, sct. 223), indicating some remove from the anthropological system of ranking various peoples according to the standard savage/barbaric/civilized division. See Human 236, 239, and 247 for further doubts about the broadly progressive model, Human 277 for the lack of a connection between higher culture and happiness, and Human 285 for an early remark on the modern degeneration. But there is some ambivalence in Nietzsche's middle period; at times his belief in the possibility of progress through science is pronounced (Nietzsche 1986b, sct. 107) For other instances of an apparent commitment to discrete kinds of progress see Human 43, 271 and 274. 
rise up to kinship with God and eternal life. (Nietzsche 1997a, sct. 49; see also Nietzsche 1999, 12 10[7])

Nietzsche senses the kind of self-affirming stakes that might be lurking behind the progressive model of development but sees no prospects for progress toward a perfected state of humanity. In the same book, he levels a similar critique, while lowering the bar on what humankind might be imagined to be progressing towards. He tells us that an end such as "the 'happiness and welfare of mankind' [is] a phrase to which it is ... impossible to attach any distinct concepts" (Nietzsche 1997a, sct. 108); and then he adds: "Evolution does not have happiness in view, but evolution and nothing else" (Nietzsche 1997a). ${ }^{16}$

Perhaps more important, for my purposes, than these broad claims is the fact that Nietzsche's skepticism about humankind's cultural progress is reflected in his programmatic statements about the genealogical method. Right in the middle of the Genealogy, Nietzsche explains that a social institution, ceremony, or custom (such as punishment) can be divided into a "fixed form of action ... a certain sequence of procedures" (Nietzsche 1997b, II. 13), and a more fluid interpretation that gets imposed on this form giving it its particular meaning or purpose in a given cultural context. This interpretation can be replaced, added to, or modified by a new meaning or use as social conditions change, and in this way the form of action or practice gets reinterpreted. As a result, over time a form of action or practice accrues "a kind of unity [of meanings] which is difficult to dissolve back into its elements" (Nietzsche 1997b). The genealogist must learn to distinguish the forms of action or practice from the meanings or purposes interpreted into these practices. The former will be an older and relatively more stable historical object. ${ }^{17}$

Nietzsche understands the imposition of interpretations on actions or practices as a matter of various power structures rising up and overtaking existing structures. He explains:

[T] here is no more important proposition for all kinds of historical research than ... that the origin of the emergence of a thing and its ultimate usefulness, its practical application and incorporation into a systems of ends are toto coelo separate; that anything in existence, having somehow come about, is continually interpreted anew, requisitioned anew, transformed and redirected to a new purpose by a power superior to it; ... overpowering and dominating consist of re-interpretation, adjustment, in the process of which their former 'meaning' and 'purpose' must necessarily be obscured or completely obliterated. No matter how perfectly you have understood the usefulness of any physiological organ (or legal institution, social custom, political usage, art form or religious rite) you have not yet thereby grasped how it emerged. (Nietzsche 1997b, II. 12)

It follows, for example, that as a new political ideology rises to power, the social practices identified with, say, punishment, marriage, or education may be reinterpreted such that they are seen as meaning something, or being for something, new. Marriage as the practice of maintaining a state-sanctioned monogamous relationship, for example, may now be about (or for) the consolidation of wealth, replacing or transforming the idea that it is about the raising of children.

The parallels between Nietzsche's thinking here and the anthropological notion of survivals are striking. Notice how Tylor speaks of survivals in this passage: "It seems scarcely too much to assert ... that meaningless customs must be survivals, that they had a practical, or at least ceremonial, intention, when and where they first arose, but are now fallen into absurdity from having been carried on into a new state of society, where their original sense has been discarded" (Tylor 1871, p. 85). Survivals are practices or beliefs that

16 In a note from 1880, Nietzsche writes that: "Humanity has no goal, just as the dinosaurs did not have one; but it has an evolution: that is, its end is no more significant than any point on its path" (Nietzsche 1999, p. 208; translation mine). And in a later note he puts it bluntly: "the human being as a species is not progressing" (Nietzsche 1999, p. 315; translation mine).

17 One of the big mistakes the "English" genealogists make is failing to make this distinction, and thus confusing the current meaning of the practice of morality (i.e., utility) with its original meaning (Nietzsche 1997b, I. 1-2). 
carry a sense or meaning associated with their intended use. While Tylor allows for the possibility of meaningless practices, Nietzsche thinks that all such practices are gathered under some new sense. Where Nietzsche more clearly departs from the anthropological sense of a survival is in his rejection of the view that the meanings imposed by power structures on various practices or procedures have progressively become more rational, or more conducive to happiness or flourishing. He writes:

[T] he whole history of a 'thing', an organ, a tradition can to this extent be a continuous chain of signs, continually revealing new interpretations ..., the causes of which need not be connected even amongst themselves, but rather sometimes just follow and replace one another at random. The 'development' of a thing, a tradition, an organ is therefore certainly not its progressus towards a goal, still less its logical progressus ... instead it is a succession of more or less profound, more or less mutually independent processes of subjugation exacted on a thing. (Nietzsche 1997b, II. 12) ${ }^{18}$

The upshot of this process of more or less random meaning shifts is that human beings in the late 19th century represent no kind of general improvement for Nietzsche. While he tells us "that 'man' is first and foremost a teeming mass of worms ... who is incurably mediocre and unedifying," he notes that this same being "has already learnt to view himself as the aim and pinnacle, the meaning of history, the 'higher man'" (Nietzsche 1997b, I. 11).

Scholars have suggested that Nietzsche's genealogies are really about locating the psychological states that explain the emergence of morality, that he is looking for the psychology behind historically decisive interpretations of practices or forms of action. ${ }^{19}$ In the broadest terms, we might say then that Nietzsche explains the concepts of good/evil (Nietzsche 1997b, I), guilt (Nietzsche 1997b, II), and asceticism (Nietzsche 1997b, III) in terms of certain types of people experiencing certain psychological states (under given conditions) that impose interpretations on practices of evaluation, on feelings of indebtedness, and on practices of self-inflicted cruelty, respectively. These psychological states are the ressentiment of an established slave class, the bad conscience of the newly enslaved type, and the melancholic depression (rooted in the physiology) of "contemplative types." These are the states that overpower others in imposing their meanings on historically embedded practices.

\section{Recurring Historical Traumas: Genealogy without a Telos}

How, if at all, does Nietzsche's familiarity with the anthropologists' reconstruction of human prehistory inform his selection of these particular interpretive events as the decisive events in the history of morality? We saw in Section 1 that the notion of a progressive development of civilization towards the end or telos of modern industrialized Europe served the anthropologists as a culturally reassuring hermeneutical tool, which also brought a fairly neat linear order to the blizzard of new anthropological facts. Nietzsche was aware of the modern need for reassurance in the face of this blizzard: "When the entire history of culture opens up before our gaze as a confusion of evil and noble, true and false conceptions, and at the sight of this surging of the waves we come to feel almost seasick, we are then able to grasp what comfort there lies in the idea of an evolving god ... it is not all a blind mechanism, a senseless, purposeless confused play of forces" (Nietzsche 1986b, p. 238). But, in the Second and Third Essays, where some of these new facts are surely relevant, Nietzsche deploys no comforting or organizing teleological framework. How, then, does he look at the long distant past in order to make sense of what has come to be in the last two millennia?

18 However, within this larger context of random changes in meaning Nietzsche does acknowledge that something counts as progress: the development of rare higher types of people. So, referring to this qualified sense of "progress" ("true progressus") he writes: "The amount of 'progress' can actually be measured according to how much has had to be sacrificed to it; man's sacrifice en bloc to the prosperity of one single stronger species of man-that would be progress" (Nietzsche 1997b, II. 12).

19 See, for example, Janaway (2007, p. 11) and Kail (2011, p. 217). 
The answer that has dominated the scholarship (particularly in the context of the Genealogy II and III) is that Nietzsche largely ignores the history; he does not worry about any surfeit of historical details because he presents a mostly fictional or mythic account. For example, Richard White denies that Nietzsche's genealogy involves "careful ... scholarship," and sees it more as a "performative critique" that draws on a "mythical prehistory" (White 1994, p. 65). Salaquarda (1996, p. 105) argues that Nietzsche's genealogy is a hypothetical reconstruction in the vein of Locke and Rousseau. Yirmiyahu Yovel says that "Nietzsche does not pretend to offer a factual picture of the past" (Yovel 1998, p. 142), and Simon May agrees saying that Nietzsche's genealogical accounts "are best taken as fictional" (May 1999, p. 52). Robert Guay tells us that "although [Nietzsche's genealogy] contains many historical allusions, the presentation is thematic or even mythical" (Guay 2006, p. 353). Most recently, P.J.E. Kail, referencing Nietzsche's prefatory boasts about a grey documented genealogy as opposed to an empty blue one, says: "[T] put it bluntly, although Nietzsche does make some historical claims in GM, the contents of that work are anything but 'grey, meticulous, and patiently documented'" (Kail 2011, p. 217). Kail allows that the First Essay's account of the slave revolt in morality is "constrained and corroborated" (Kail 2011, p. 231) by the historical record, but dismisses the historical credentials of the Second Essay saying: "A good many of the explananda-such as the emergence of bad conscience-lie in prehistory, beyond the reach of any 'grey documentation'" (Kail 2011, p. 218).

In fairness to Kail, the historical specificity of the First Essay in discussing Rome around the time of Jesus does give way in the Second Essay to the bare distinction between history and prehistory, while in the Third Essay all talk of history seems to vanish almost entirely in Nietzsche's focus on the universality of asceticism. However, we will see now that the Second Essay, and to a lesser extent the Third Essay, are also constrained and corroborated (to use Kail's phrase) by the conclusions of contemporary anthropology. Nietzsche structures his account of the "conditions and circumstances under which" (Nietzsche 1997b, Pref. 6) morality emerges in terms of an understanding of it both "as result, as symptom, as mask, as tartuffery, as sickness, as misunderstanding; but also morality as cause, remedy, stimulant, inhibition, poison" (Nietzsche 1997b). Morality, then, is at one and the same time both the effect or symptom of sickness and the stimulating, but poisonous, cure for this sickness. Both the Second and Third essays demonstrate that Nietzsche's genealogical method involves looking to the anthropological record for recurring patterns of trauma that can explain how morality as a symptom of sickness emerges. In the case of the Third Essay, we will also see the supposed remedial dimension of morality in responding to this sickness. My focus in the rest of this paper will be less on the precise details of Nietzsche's arguments on bad conscience and asceticism, and more on how he uses the anthropological evidence to pick out the historical roots of both.

\subsection{The Development of Bad Conscience in the Second Essay}

In broad terms, Nietzsche's explanation of guilt in the Second Essay is built around the idea that bad conscience as a psychological state takes up and re-interprets the practice of feeling indebted that first emerges in the context of the earliest economic relations but is later applied to a community's primitive relations with its ancestors/gods (Nietzsche 1997b, II. 19-21). However, one of the glaring problems in the essay is the simple chronological matter of when Nietzsche thinks the traumatic events that initiate the formation of the sickly psychological state of bad conscience occur. Do these events represent the beginning of all human sociality, or are they somehow further down the line in the history of human society? This is the kind of question a genealogy worthy of the name should surely answer.

The overwhelming consensus amongst scholars is that Nietzsche imagines the violent conquering and entrapment of a large, loosely bound population described in sections 16 and 17 of the Second Essay - that is to say, the events that set the stage for the internalization of aggressive instincts and the formation of bad conscience-as the foundation for all 
human socialization. Bernard Reginster, for example, thinks that for Nietzsche humans are pre-social prior to these events:

Nietzsche's conception of the "state of nature," prior to socialization, is not, as it is for Freud, the helpless and dreadful state of individuals ill-suited for solitary life in nature. Nietzsche's presocial individual is, on the contrary, "happily adapted to the wilderness, war, the wandering life and adventure." Nietzsche, therefore, assumes that it must have taken "an act of violence" to tear him away from this state of happy adaptation (GM II. 17). And he attributes this initial act of violence to a small group of strong individuals. (Reginster 2011, p. 62)

Ridley (1998, pp. 18-19) concurs, arguing that any form of socialization at all involves the severe imposition of customs and the development of bad conscience, and thus that (outside of the mysterious conquering tribes) there is no socialization prior to what is described in sections 16 and 17 of the Second Essay. Mathias Risse also agrees, arguing that prior to these events: "people are living more or less by themselves, following their instincts for food, shelter ..." " (Risse 2001, p. 57). While Brian Leiter does not make any definitive claims on this front, he does say that the "dramatic development" described in sections 16 and 17 "made civilization and social intercourse possible" (Leiter 2002, p. 234; see also Jenkins 2003, p. 70; Katsafanas 2016, p. 57; Metzger 2020, p. 131). The clear suggestion here is that social intercourse, and thus human society, is not possible prior to this development.

This reading of Nietzsche on the beginnings of human sociality is surely part of the picture for those scholars who think the Genealogy offers a kind of mythical prehistory. It is a reading that certainly puts Nietzsche at odds with the scientific consensus of contemporary anthropologists on the issue of the first human societies. Though the anthropologists had numerous disagreements, Adam Kuper concludes that:

[B]y the last decade of the nineteenth century, almost all the new specialists would have agreed with the following propositions.

1. The most primitive societies were ordered on the basis of kinship relations.

2. Their kinship organization was based on descent groups.

3. These descent groups were exogamous and were related by a series of marriage exchanges.

4. Like extinct species, these primeval institutions were preserved in fossil form, ceremonies and kinship terminologies bearing witness to long dead practices.

5. Finally, with the development of private property, the descent groups withered away and a territorial state emerged. This was the most revolutionary change in the history of humanity. (Kuper 1988, p. 7)

These claims provide a broad framework of agreement for all the figures Nietzsche read, and there is no place in this framework for a founding act of violence. Since Nietzsche seems to have been paying especially close attention to Post's Bausteine für eine allgemeine Rechtswissenschaft auf vergleichend-ethnologischer Basis during the writing of the Genealogy, we shall use Post's thinking to lay out some more of the kinds of details that filled out this broad framework.

At the heart of Post's vision of prehistoric humans in Bausteine is the distinction between the peace cooperative (Friedensgenossenschaft) and the state. Post thinks that the general tendency is for human society to develop from a peace cooperative into a state, but he complicates things by acknowledging that both kinds of social organization show up in many different forms and thus that he can only define each one in terms of typical characteristics. It is typical of the original form of peace cooperative, the Geschlechtsgenossenschaft or kin-based community, that all property is held in common, that outlawry (i.e., exclusion from the protection of the community) is the most common form of punishment, and that all community members share responsibility for avenging the death of one of their own and are subject to being held responsible by another community for such a loss. Meanwhile, 
typically, in the state, leadership is severed from blood ties, there is individual property, and individual arrest for crimes under a public criminal law (Post 1881, p. 6). Tracking the shift from a nomadic hunter gatherer community to an agricultural one, Post argues for more developed, settled forms of peace cooperative-the Gaugenossenschaft or peasant community, and the Hausgemeinschaft or house community-while insisting that many societies have demonstrated features of both the peace cooperative and the state, and that it is often very unclear whether a particular formation counts as a peace-cooperative or a state (Post 1880, p. 47).

Without acknowledging his source, Nietzsche adopts Post's classification of prehistoric social formations in his Second Essay descriptions of the way feelings of indebtedness towards ancestors develop: "Within the original clan association (ursprünglichen Geschlechtsgenossenschaft) —we are speaking of primeval times-the living generation always acknowledges a juridical obligation to the earlier generation" (Nietzsche 1997b, II. 19). Not only is Nietzsche borrowing Post's language here, but he is explicitly accepting Post's view on the prehistoric originality of such a formation in referring to the "original (ursprünglichen)" pre-state human communities. Nietzsche also references these kin-based communities a section later when he describes what happens after the "decline of the 'community' organized according to blood relationships (blutverwandtschaftlichen)" (Nietzsche 1997b, II. 20). This is an implicit reference to the rise of states at the expense of peace-cooperatives organized around blood ties, which is the same kind of matter more dramatically covered in sections 16 and 17 of the Second Essay.

It seems then that Nietzsche's thinking in the Genealogy is consistent with the anthropological framework according to which prehistoric, pre-state communities were made up of kin-based descent groups. In fact, Nietzsche even accepts Post's claims to the effect that these first communities were egalitarian and held property in common. In discussing how the root words for "good" go back to the way in which ancient nobles referred to themselves, Nietzsche says in a parenthetical remark: "who will guarantee us that modern democracy, the even more modern anarchism, and in particular that inclination toward the 'commune,' the most primitive form of society [ ... ] does not signify on the whole, a tremendous atavism" (Nietzsche 1997b, I. 5). Nietzsche's reference to a commune here calls on the idea that the Friedensgenossenschaft is, at least initially, egalitarian and communistic in its attitudes towards property (movable and immovable).

What, then, are we to make of the events described in sections 16 and 17? How do they fit with the idea of the original kin-based community? Rather than reading the decisiveness of these events as a matter of their producing the first human society, I think Nietzsche is pointing to their decisively traumatizing nature as a kind of socialization that completely cuts off the instinctual life of a community. Conquering tribes have warred with and enslaved other tribes throughout human history, but in sections 16 and 17 Nietzsche draws on the anthropological evidence to portray an extreme instance of such a recurring event. This portrayal of maximal trauma throws Nietzsche's argument for the psychological formation of bad conscience into starkest relief. The extreme disparity between the opposing forces, even though both are instances of "prehistoric tribes," broadly understood, gives us the most unequivocal and thus instructive case of bad conscience. Let us take a quick look at the anthropological evidence behind Nietzsche's conceptions of these forces.

Post makes it clear that even the most basic social formation, the Geschlechtsgenossenschaft, is an ordered formation of sorts. ${ }^{20}$ However, for Post, it is equally the case that the earliest blood-based community (Blutsverwandschaft) had relatively few customs (Post 1880, p. 41). This picture fits with Lubbock and Caspari, both of whom present the "lowest" cultural formations as akin to herds of animals wandering the wilderness together. For

20 In discussing the adoption of strangers into such a kin-based community, for example, Post talks of such adopted agents having "all the rights and obligations (alle Rechte und Pflichten)" (Post 1881, p. 18) of the others. 
example, consider this passage in which Lubbock quotes from Father Baegart's 18th century account of Californian Indians:

They had no magistrates, no police, and no laws; idols, temples, religious worship or ceremonies were unknown to them, and they neither believed in the true or only God, nor adored false deities. They were all equals, and everyone did as he pleased, without asking his neighbor or caring for his opinion, and thus all vices and misdeeds remained unpunished, excepting such cases in which the offended individual or his relations took the law into their own hands and revenged themselves on the guilty party. The different tribes represented by no means communities of rational beings, who submit to laws and regulations and obey their superiors, but resembled far more herds of wild swine, which run about according to their own liking, being together to-day and scattered to-morrow, till they meet again by accident at some future time. (Lubbock 1875, p. 314)

The description of the conquered peoples in section 17 as an "unrestrained and shapeless [... ] and shifting" population clearly echoes this kind of account.

Nietzsche found the same kind of thing in Caspari (1877), who draws a strong distinction between those social animals that merely herd or swarm together in large numbers for procreation and safety, and those that are more organized in dividing labor, following customary practices, enumerating the size of their group, and providing for the care of their young (leading to stronger social bonds) (Caspari 1877, pp. 110-14). Though Caspari clearly identifies prehistoric humans with the latter category of social animal, he cites examples of indigenous peoples who barely rise above the condition of a swarm and easily fall back into such a condition where there are only vestiges of customs and organization (Caspari 1877, pp. 113-14). Such a human herd is largely leaderless, customless, and thus shapeless. Lubbock and Caspari, then, both acknowledge the possibility of the most rudimentary tribal entities existing at the same time as far more organized and disciplined groups.

The corollary of the view that the most "primitive" communities are more egalitarian and less organized is Post's view that development in a Friedensgenossenschaft amounts to greater organization, social stratification, and even singular tribal leadership. Nietzsche's interest must surely have been piqued when he found both Lubbock $(1875$, p. 345) and Post (1881, p. 9) arguing that war, conquering, and enslavement are decisive in driving these kinds of developments within a tribe. ${ }^{21}$ As we saw above, Post thinks that the capture of slaves first leads to the conception of a nobility or higher class within a tribe (Post 1880, p. 42). War, and any subsequent enslavement of enemies, encourages the processes of organization and stratification that further promote success in war; this process leads some tribes toward greater organization and strength, and thus the incorporation of other groups. It is surely from these kinds of considerations that Nietzsche draws his conception of a small band of conquerors in sections 16 and 17. He says that they are "a conqueror and master race ... organized on a war footing, and with the power to organize"

21 See Beyond Good and Evil 262 for Nietzsche's views about how "unfavorable conditions" breed stronger types. War is such a condition. 
(Nietzsche 1997b, II. 17). ${ }^{22}$ They are a well-organized tribe, practiced in war and taking slaves, and on the cusp of expansion into a state. ${ }^{23}$

The ethnological research of the day makes conflict between these radically different kinds of tribes a real historical possibility. The kind of conflict Nietzsche describes in sections 16 and 17 is a maximally imbalanced conflict in a long history of clashes between tribes of differing strengths, ages, and phases of development. Consider, for example, Nietzsche's suggestion in Beyond Good and Evil that every "higher culture on earth" began when: "Human beings whose nature was still natural, barbarians in every terrible sense of the word, men of prey who were still in possession of unbroken strength of will and lust for power, hurled themselves upon weaker, more civilized, more peaceful states, perhaps traders or cattle raisers, or upon mellow old cultures, whose last vitality was even then flaring up in splendid fireworks of spirit and corruption" (Nietzsche 1989, sct. 257). The enslavement of an old, jaded culture practiced in submission to law would have gone differently from the events described in sections 16 and 17, with different psychological implications for the enslaved, likely producing a lesser degree of internalized aggression and thus bad conscience (Nietzsche 1997b, III. 9). That being said, however people end up "finally ... imprisoned within the confines of society and peace" (Nietzsche 1997b, II. 16), the maximal case most clearly exemplifies the point that this state represents one in which the natural instincts of the conquered are choked off and must turn back. Where a culture is incorporated by a neighboring tribe sharing similar practices, bad conscience may develop but to a lesser extent.

The psychological implications of the trauma undergone by the conquered tribe in sections 16 and 17 can best be understood by returning to Nietzsche's genealogical model of practices or forms reinterpreted through time. For Nietzsche, the basic customary practices of a community arise out of their shared instincts for survival (Nietzsche 1986b, sct. 96; Nietzsche 1986a, sct. 89; Nietzsche 1986c, sct. 44; Nietzsche 2001, sct. 116). Therefore, the practices of a Geschlechtsgenossenschaft will reflect its instinctive dispositions and any shifts in conditions that express themselves in valuing new instincts will be reflected in the shifting interpretations of these practices. Fundamentally, then, customary or habitual practices are a function of a community's deepest and oldest drives and affects, and any of the interpretations and reinterpretations imposed on these practices will capture shifts in these drives and affects. All of this is suddenly cut off in the lives of the conquered in (Nietzsche 1997b, II. 16-17); they differ radically from their conquerors, and so there will hardly even be shared practices that now get re-interpreted under the new regime. Instead, the drive-based psychological expressions and outlets of the conquered tribe are simply cut off and the slaves are violently forced into a pre-made system of order and function, their practices and customs completely dictated to them. The trauma of enslavement for such a group is followed, then, by a complete damning up of instinctual expression. This provides Nietzsche with the clearest instance of internalization, the "serious illness" (Nietzsche 1997b, II. 16) humankind was subjected to by recurring traumas of enslavement. Bad conscience is the psychological effect of such recurring human traumas.

22 My approach to sections 16 and 17 of the Second Essay solves at least one significant problem with the standard reading of these sections. This reading leaves it altogether mysterious who the smaller, more organized conquering tribes are, how they came about, and how they regulated themselves such that they could express the kind of future-oriented thinking and planning necessary to establish the oldest state. If their arrival represents the first moment in Nietzsche's history of morals, then we are left with a big gap where we could have an explanation of their emergence.

23 This understanding of the events described in sections 16 and 17 suggests that behind Nietzsche's genealogy of morality lies the following threefold division of history: an early period in prehistory that stretches over vast amounts of time and is peopled by various kinds of kinship-based tribes, a middle period, which forms the transition from prehistory to history, and in which strictly stratified "states" appear, and a later historical period, which Nietzsche identifies with the Judeo-Christian slave revolution in the West. Nietzsche references a threefold division when he contrasts "the longest period of the human race, prehistory ... [with] the middle period (mittlere Zeit), in which the noble clans developed" (Nietzsche 1997b, II. 19; translation modified). Nietzsche is not saying that—contrary to the well-known binary distinction between prehistory and history-there are actually three historical periods, but rather that the move from prehistory to history involves an intermediate or middle period (mittlere Zeit) that allowed for this transition. And so, prehistory begins to end with the move into the "middle period," which is initiated by the violent creation of "states" that allow governing nobles to emerge fully. The noble clans "develop" or "emerge" (herausbilden) during this middle period because nobility requires slaves in order to become nobility; a pathos of distance must develop to afford the noble class its elevated sense of itself. 


\subsection{Asceticism in the Third Essay}

The development of bad conscience amongst numerous enslaved populations is just one element in man's sickly condition, the condition for which ascetically infused moral values are a supposed remedy. In turning to the Third Essay, I shift focus to another dimension of this sickness, another recurring pattern of trauma that the asceticism in morality supposedly treats. In short, though bad conscience and the ascetic ideal occupy very different places or roles in Nietzsche's target explanandum (i.e., morality), both are traced back to recurring trauma. In the case of asceticism, Nietzsche broadens the lens beyond the psychological effects of an enslavement that cuts off instinctual expression to consider human sickness as a physiological matter. He identifies recurring patterns of human suffering of epidemic proportions that produce a kind of nervous sickness for which the ascetic priest, by reinterpreting certain practices, proposes a cure. In providing this analysis, Nietzsche is constrained and corroborated by the anthropological record on the origin of ascetic practices and by the historical records of events of mass suffering.

For Nietzsche, the (essay's titular) meaning of the ascetic ideal is about the origin and power of this ideal (Nietzsche 1997b, III. 23). The fundamental origin of the ascetic ideal lies in human sickliness: "the ascetic ideal springs from the protective and healing instincts of a degenerating life, which uses every means to maintain itself and struggles for its existence" (Nietzsche 1997b, III. 13). Meanwhile, its power is a function of the pervasiveness of this sickliness: "The fact that, as history tells us, this ideal could rule man and become powerful to the extent that it did ... reveals a major fact, the sickliness of the type of man who has lived up till now" (Nietzsche 1997b). Nietzsche describes this sickliness in physiological terms as a kind of "inhibition and exhaustion" that recurs throughout human history as a result of epidemics of being fed up or overfilled with various kinds of mass suffering (e.g., the suffering during the Black Death in the 14th century (Nietzsche 1997b, III. 13), or the suffering associated with mass migrations (Nietzsche 1997b, III. 17)). I argue elsewhere that "inhibition and exhaustion" are conditions of the nervous system that arise in the face of a surfeit of some kind of suffering with which we cannot cope (Nietzsche 1997b, III. 13 and 16). This physiological condition gets expression in widespread feelings of depression, listlessness, melancholy, etc., for which the ascetic ideal is the supposed cure.

The ascetic ideal, then, which is created by the quintessentially sick person (i.e., the sick contemplative or priest), is not created in a singular historical moment but is recreated over and over as "regularly and universally" as the ascetic priest makes his appearance (Nietzsche 1997b, III. 11). And there is always an audience of sickly masses ready for this ideal to soothe them by convincing them that they "'too good' for this world" (Nietzsche 1997b, III. 1). We are back, then, in the realm of a recurring historical pattern around the site of trauma (just as we were with conquering and enslavement). In this case, the trauma is a surfeit of suffering, which produces the sense that one cannot cope with life (i.e., nervous inhibition and exhaustion). The ascetic ideal is a false remedy for this trauma, and resulting nervous sickness, in that it provides temporary relief by exciting the sick person, while ultimately only making the original condition worse (Nietzsche 1997b, III. 21).

We can understand the origins of this ideal in terms of how sickly contemplatives impose an ascetic interpretation on practices originally interpreted as signs of divine possession. For Nietzsche, the contemplatives are the original sufferers from an excess of suffering and they are most sophisticated in managing it. In Daybreak 42 (Nietzsche 1997b, III. 10), Nietzsche describes the original contemplative "in rude ages" as one who disengages from a life of activity either through old age, weariness, or illness, and redirects his unspent aggressive instinctual energy into critical thought. To add to the first-order suffering associated with such a withdrawal from the customary life of activity, these men are "despised (verachtet) when they were not feared" (Nietzsche 1997b, III. 10). Their "inactive, brooding" (Nietzsche 1997b) lifestyle flaunts custom and makes them targets of mistrust (and even self-mistrust), thus increasing their misery. Nietzsche writes that "they had no other remedy than to arouse a pronounced fear of themselves" (Nietzsche 1997b) and 
they did this with "terrible methods: cruelty towards themselves, imaginative forms of self-mortification" (Nietzsche 1997b). These are the first ascetic procedures or practices, and their original meaning was associated with possession by extraordinary forces; that is to say, the capacity for such practices indicated a kind of madness that one ought to respect, or at least fear. The logic is that only mad people would hurt themselves, and madness may be a sign of possession by a deity.

Nietzsche draws on Lubbock for anthropological support for this origin story. Discussing primitive religions, Lubbock writes: "Hence it is that mad people are in many countries looked on with so much reverence, since they are regarded as the special abode of some deity" (Lubbock 1875, p. 216). Additionally, Lubbock notes that this madness often takes the form of an ability "to endure excessive fatigue, want of food, and intense prolonged mental excitement" (Lubbock 1875, p. 244), pointing out that in some tribes inducing these states of madness is part of a process of becoming a Shaman:

The Greenlander ... who would be an angekok, must retire from all mankind for a while into some solitary recess or hermitage, must spend his time in profound meditation ... At length, by abandoning the converse of men, by fasting and emaciating the body, and by a strenuous intenseness of thought, the man's imagination grows distracted, so that blended images of men, beasts, and monsters appear before him. He readily thinks these are real spirits. (Lubbock 1875, p. 245)

Later, Lubbock explains that in certain tribes the prophet: "works himself into a state in which he can see departed spirits ... [such prophets] are nervous excitable men ... and in giving oracles they go into actual convulsions" (Lubbock 1875, p. 334).

Nietzsche directly references Lubbock's Greenlander example in the same passage in which he focuses on the idea of prehistoric contemplatives operating under the guise of madmen, who are the "mask and speaking-trumpet of a divinity" (Nietzsche 1997a, sct. 14). ${ }^{24}$ However, Nietzsche goes beyond Lubbock, taking the anthropological claims up in a larger conjecture about how and why these practices were reinterpreted and given a meaning associated with the ascetic ideal. One way to think about this is that the ascetic ideal emerges because these self-mortifying practices, though socially useful to some extent, only worsen the suffering of the contemplative. The emotional excesses associated with these practices just increase the nervous exhaustion of the contemplative (Nietzsche 1997b, I. 6), and under these conditions his "protective and healing instincts" (Nietzsche 1997b, III. 13) make use of his resentful rage at the conditions of existence (i.e., "appearance, transience, growth, death, wishing, longing" (Nietzsche 1997b, III. 28)) that have led him to suffer so much. Nietzsche writes: "For an ascetic life is a self-contradiction: here an unparalleled ressentiment rules, that of an unfulfilled instinct and power-will which wants to be master ... over life itself and its deepest, strongest, most profound conditions" (Nietzsche 1997b, III. 11).

Ascetic practices, then, are no longer read as signs of possession, but are understood as the symbolic renunciation of the corporeal world. The priest's body stands in for the whole world, which is rejected in a flight into another world in this new meaning. Nietzsche writes:

The idea we are fighting over here is the valuation of our lives by the ascetic priest: he relates this (together with all that belongs to it, 'nature', 'the world', the whole sphere of what becomes and what passes away) to a quite different kind of existence which is opposed to it and excludes it unless it should turn against itself and deny itself: in this case, the case of the ascetic life, life counts as a bridge to that other existence. (Nietzsche 1997b, III. 11)

Additionally, Nietzsche is clear about how he understands the historical recurrence of this revaluation: "Such a monstrous method of evaluation is not inscribed in the records of human history as an exception and curiosity: it is one of the most wide-spread and long-lived

24 The same cluster of ideas (madness, self-mortification, and divine inspiration) comes up in Human 127, as well as Daybreak 18 and 42. 
facts there are" (Nietzsche 1997b). Moreover, this is an interpretation of the body that finds new audiences throughout history as community after community undergoes traumatic suffering with which they cannot cope. As they grow sick with nervous exhaustion and the accompanying feelings of depression and listlessness, the ascetic ideal (with its promise of another world and demands for the renunciation of this world) infuses them with the fleeting vitality of strong feelings.

\section{Conclusions}

We saw in Section 1 above that the anthropologists' developmental or progressive model of social history answered two needs: it provided a rational framework of sorts into which these scholars could fit the overwhelming amounts of data that flooded their field. Moreover, in ranking indigenous (and thus prehistoric) societies against the gold standard of modern European culture, the developmental model assured the cultural superiority of the latter in a time of social and cultural uncertainty. Though we have seen that Nietzsche learns a lot from the anthropologists, his genealogical work in the Genealogy II and III tracks the psychological effects of human trauma (whether it be the traumas of war and enslavement, or of mass suffering induced by migrations, epidemic diseases, etc.) through to the moral phenomena of guilt and asceticism, and thus dispenses entirely with any organizing or comforting teleological paradigm. Indeed, Nietzsche sees the very events that the anthropologists regard as impetuses to social progress (e.g., war, enslavement, migration, etc.) as occasions for the kinds of traumas that produce lasting psychological and, ultimately, moral shifts in human society. Though these traumas may have made the human a more "interesting animal" (Nietzsche 1997b, I. 6; see also Nietzsche 1997b, II. 16), Nietzsche does not consider them the price we pay for progress. They are, instead, lingering wounds that we must somehow learn to turn to our advantage.

Funding: This research received no external funding.

Institutional Review Board Statement: Not applicable.

Informed Consent Statement: Not applicable.

Data Availability Statement: Not applicable.

Conflicts of Interest: The author declares no conflict of interest.

\section{References}

Bowler, Peter. 1988. The Non-Darwinian Revolution: Reinterpreting a Historical Myth. Baltimore: Johns Hopkins University Press.

Burrow, J. W. 1966. Evolution and Society: A Study in Victorian Social Theory. Cambridge: Cambridge University Press.

Caspari, Otto. 1877. Die Urgeschichte der Menschheit. Leipzig: F. A. Brockhaus.

Clark, Maudemarie, and J. Alan Swensen, eds. 1998. On the Genealogy of Morality. Indianapolis: Hackett.

Craig, Edward. 2007. Genealogies and the State of Nature. In Bernard Williams. Edited by Alan Thomas. Cambridge: Cambridge University Press.

Deleuze, Gilles. 1983. Nietzsche and Philosophy. Translated by Hugh Tomlinson. London: Athlone.

Guay, Robert. 2006. The Philosophical Function of Genealogy. In A Companion to Nietzsche. Edited by Keith Ansell-Pearson. Oxford: Blackwell.

Janaway, Christopher. 2007. Beyond Selflessness: Reading Nietzsche's Genealogy. New York: Oxford University Press.

Jenkins, S. 2003. Morality, Agency, and Freedom in Nietzsche's Genealogy of Morals. History of Philosophy Quarterly 20: 61-80.

Kail, P. J. E. 2011. 'Genealogy' and the Genealogy. In Nietzsche's on the Genealogy of Morality: A Critical Guide. Edited by Simon May. Cambridge: Cambridge University Press.

Katsafanas, Paul. 2016. The Nietzschean Self. Oxford: Oxford University Press.

Kuper, Adam. 1988. The Invention of Primitive Society: Transformations of an Illusion. New York: Routledge.

Leiter, Brian. 2002. Nietzsche on Morality. New York: Routledge.

Lubbock, John. 1875. The Origin of Civilization and the Primitive Condition of Man: Mental and Social Condition of Savages, 3rd ed. London: Longmans, Green, and Co.

May, Simon. 1999. Nietzsche's Ethics and his War on Morality. New York: Clarendon Press.

Metzger, Jeffrey. 2020. The Rise of Politics and Morality in Nietzsche's Genealogy: From Chaos to Conscience. Lanham: Lexington Books.

Mill, John Stuart. 2006. Collected Works of John Stuart Mill. Indianapolis: Liberty Fund, vol. 8.

Moore, Gregory. 2002. Nietzsche, Biology and Metaphor. Cambridge: Cambridge University Press. 
Nietzsche, Friedrich. 1986a. Assorted Opinions and Maxims. Translated by R. J. Hollingdale. Cambridge: Cambridge University Press. Nietzsche, Friedrich. 1986b. Human, All Too Human. Translated by R. J. Hollingdale. Cambridge: Cambridge University Press.

Nietzsche, Friedrich. 1986c. The Wanderer and His Shadow. Translated by R. J. Hollingdale. Cambridge: Cambridge University Press.

Nietzsche, Friedrich. 1989. Beyond Good and Evil. Translated by Walter Kaufmann. New York: Vintage Books.

Nietzsche, Friedrich. 1997a. Daybreak. Translated by R. J. Hollingdale. Cambridge: Cambridge University Press.

Nietzsche, Friedrich. 1997b. On the Genealogy of Morality. Translated by Carol Diethe. Cambridge: Cambridge University Press.

Nietzsche, Friedrich. 1999. Kritische Studienausgabe. Edited by Giorgio Colli and Mazzino Montinari. Munich: Deutscher Taschenbuch Verlag and Walter de Gruyter, 15 vols.

Nietzsche, Friedrich. 2001. The Gay Science. Translated by Josefine Nauckhoff. Cambridge: Cambridge University Press.

Owen, David. 2007. Nietzsche's Genealogy of Morality. Stocksfield: Acumen.

Post, Albert Hermann. 1880. Bausteine für Eine Allgemeine Rechtswissenschaft auf Vergleichend Ethnologischer Basis. Oldenburg: Schulze, Erster Band.

Post, Albert Hermann. 1881. Bausteine für Eine Allgemeine Rechtswissenschaft auf Vergleichend Ethnologischer Basis. Oldenburg: Schulze, Zweiter Band.

Rée, Paul. 2003. Basic Writings. Edited and Translated by Robin Small. Urbana: University of Illinois Press.

Reginster, Bernard. 2011. The Genealogy of Guilt. In Nietzsche's "On the Genealogy of Morality": A Critical Guide. Edited by Simon May. Cambridge: Cambridge University Press.

Ridley, Aaron. 1998. Nietzsche's Conscience: Six Character Studies from the "Genealogy". Ithaca: Cornell University Press.

Risse, Mathias. 2001. The Second Treatise in On the Genealogy of Morality: Nietzsche on the Origin of the Bad Conscience. European Journal of Philosophy 9: 55-81. [CrossRef]

Salaquarda, Jörg. 1996. Nietzsche and the Judeo-Christian Tradition. In Cambridge Companion to Nietzsche. Edited by Kathleen Higgins and Bernd Magnus. Cambridge: Cambridge University Press.

Schuringa, Christoph. 2014. Nietzsche's Genealogical Histories and his Project of Revaluation. History of Philosophy Quarterly 31: 249-69.

Thatcher, David. 1983. Nietzsche's Debt to Lubbock. Journal of the History of Ideas 44: 293-309. [CrossRef]

Tylor, Edward. 1871. Primitive Culture: Researches into the Development of Mythology, Philosophy, Religion, Art, and Custom. London: John Murray.

Whately, Richard. 1832. Introductory Lectures on Political Economy. London: B. Fellowes.

White, Richard. 1994. The Return of the Master. In Nietzsche, Genealogy, Morality: Essays on Nietzsche's Genealogy of Morals. Edited by Richard Schacht. Berkeley: University of California Press.

Yovel, Yirmiyahu. 1998. Dark Riddle: Hegel, Nietzsche and the Jews. University Park: Penn State University Press. 